JURNAL SEKRETARIS DAN ADMINISTRASI BISNIS

Journal homepage htp tljurnal a mobac ad/indexphp/jsab

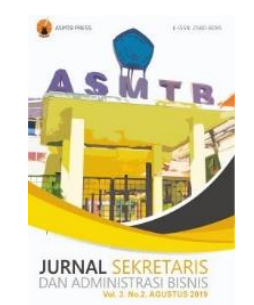

The Effectiveness of Electronic Archive System of Human Resource Information System (HRIS): A Case at PT Konimex Solo

\title{
Efektivitas Sistem Kearsipan Elektronik Human Resource Information System (HRIS):
} Studi pada PT Konimex Solo

${ }^{1)}$ Claudia Trivena, ${ }^{2)}$ Yunita Budi Rahayu Silintowe

${ }^{1,2)}$ Faculty of Economics and Business, Universitas Kristen Satya Wacana

1)102014014@student.uksw.edu, ${ }^{2)}$ yunita.silintowe@uksw.edu

\begin{tabular}{l} 
Article info \\
\hline Article history: \\
Received $2^{\text {nd }}$ May 2019 \\
Received in revised form $7^{\text {th }}$ May 2019 \\
Accepted 20 th August 2019
\end{tabular}

Keywords:

Filing,

Electronic filing system,

Effectiveness

\begin{abstract}
With the development of information technology can create an electronic filing system that is useful for storing documents in the form of soft files. Realizing the effectiveness of the electronic filing system, several aspects need to be considered, namely speed, convenience, efficiency and, safety. In this study, we want to see how effective the electronic filing system is applied to PT Konimex Solo especially in the Human Resource Department. The researcher used qualitative descriptive research. The informants in this study were the Head of Recruitment Administration Section, Recruitment Administration Staff, HRD Administration Staff, and Personnel Section Staff. The results of the study indicate that the Human Resource Department of PT Konimex Solo has been effective in using the electronic filing system "HRIS: Human Resource Information System".
\end{abstract}




\section{Pendahuluan}

Dalam suatu perusahaan pasti memiliki suatu bagian khusus untuk bertugas dalam bidang administrasi. Semakin tinggi aktivitas dan dinamika perusahaan, maka hal itu akan membuat bertambahnya kebutuhan akan informasi dalam pengambilan keputusan pada perusahaaan untuk mencapai tujuan perusahaan. Kegiatan administrasi pada dasarnya adalah menghasilkan, menerima, mengolah, dan menyimpan berbagai surat, formulir, laporan, dan dokumen lainnya. Arsip adalah suatu kumpulan dokumen yang disimpan secara sistematis karena mempunyai suatu kegunaan agar setiap kali diperlukan dapat ditemukan kembali dengan cepat (Gie, 2000). Inti dari adanya manajemen kearsipan yakni untuk menemukan kembali arsip yang tersimpan dengan cepat, lengkap dan tepat.

Kearsipan menjadi hal yang cukup berperan dalam penyimpanan dokumen-dokumen yang berada di perusahaan. Menurut kamus administrasi kearsipan (filing) adalah suatu bentuk pekerjaan tata usaha yang berupa penyusunan dokumen-dokumen secara sistematis sehingga bilamana diperlukan lagi, dokumen itu dapat ditemukan kembali secara cepat. Kearsipan tidak berfokus pada penyimpanan saja namun bertumpu pada kecepatan penemuan dokumen yang tersimpan (Sugiarto \& Wahyono, 2005).

Dewasa ini teknologi berkembang dengan sangat pesat. Dalam hitungan jam, menit bahkan detik manusia selalu menemukan hal-hal baru untuk perkembangan teknologi. Teknologi berkembang sesuai dengan kebutuhan manusia. Perkembangan dalam bidang teknologi informasi salah satunya. Seseorang dapat memperoleh berbagai informasi hanya dengan mengusap layar smartphone. Perkembangan teknologi informasi juga berdampak pada sistem kearsipan.

Sistem kearsipan elektronik adalah salah satu bukti kemajuan teknologi dalam bidang informasi. Sistem kearsipan elektronik memiliki peran yang sama dengan kearsipan konvensional. Pada kearsipan konvensional memiliki rak, lemari, map, dan lembar arsip secara fisik. Sedangkan kearsipan elektronik memiliki kabinet virtual yang didalamnya memiliki map virtual, di dalam map virtual berisi lembaran-lembaran arsip yang telah dikonversi ke dalam bentuk file gambar (bmp, jpg, dll) atau dokumen (doc, txt, dll) (Sugiarto \& Wahyono, 2005).

Dapat disimpulkan pada kearsipan konvensional memiliki rak, map, dan dokumen secara fisik, namun pada kearsipan elektronik memiliki rak, map, dan dokumen secara virtual dalam bentuk file (Sugiarto \& Wahyono, 2005). Kearsipan eletronik dapat menghemat space ruangan kerja, karena kabinet-kabinet penyimpanan dalam bentuk fisik dapat diminimaliskan dengan penyimpanan pada komputer. Berikut adalah tabel yang menunjukan perbedaan kearsipan konvensional dan kearsipan elektronik. 
Tabel 1.

Perbedaan Komponen Kearsipan Konvensional dan Elektronik

\begin{tabular}{|l|l|l|}
\hline \multicolumn{1}{|c|}{ Komponen } & \multicolumn{1}{|c|}{ Kearsipan Konvensional } & \multicolumn{1}{c|}{ Kearsipan Elektronik } \\
\hline Kabinet & $\begin{array}{l}\text { Berupa rak atau lemari arsip yang } \\
\text { dibuat secara fisik. }\end{array}$ & Berupa kabinet virtual yang dibuat dengan database. \\
\hline Map & $\begin{array}{l}\text { Berupa map fisik untuk } \\
\text { menyimpan lembaran arsip. }\end{array}$ & $\begin{array}{l}\text { Berupa map virtual atau folder untuk menyimpan file } \\
\text { dokumen. }\end{array}$ \\
\hline Arsip & $\begin{array}{l}\text { Lembaran-lembaran surat hard } \\
\text { copy. }\end{array}$ & $\begin{array}{l}\text { Lembaran-lembaran surat yang sudah di transfer ke dalam file } \\
\text { gambar/text. }\end{array}$ \\
\hline
\end{tabular}

Sumber: Sugiarto \& Wahyono (2005)

Durasi waktu untuk menemukan kembali arsip yang disimpan terkadang menjadi suatu masalah karena semakin lama waktu untuk mencari suatu arsip yang disimpan semakin menunjukan bahwa sistem kearsipan yang digunakan sangat tidak efektif. Dengan munculnya sistem kearsipan elektronik diharapkan arsip yang tersimpan dapat ditemukan kembali secara cepat, dan pengehematan space ruang kerja juga dapat dilakukan.

Penelitian sebelumnya mengenai Efektivitas Penerapan Manajemen Kearsipan Elektronik di Yayasan Perguruan Tinggi Kristen Satya Wacana, menghasilkan bahwa penerapan manajemen kearsipan elektronik di Yayasan tersebut belum dilakukan secara maksimal. Masih banyak kendala yang dihadapi yaitu masih kurangnya kapasitas penyimpanan, aksesbilitas yang kurang optimal, dan fitur yang masih sederhana (Silintowe \& Sugiarto, 2013). Dalam penelitian yang dilakukan oleh Alam (2015) menyatakan bahwa sistem kearsipan elektronik mampu memindahkan dokumentasi atau mengorganisasi file satu otoritas ke otoritas lain. Sistem yang dikembangkan dan diimplementasikan mampu mengurangi dokumentasi kertas, tekanan fisik, dan memberikan keamanan tinggi di setiap data. Sistem kearsipan elektronik bermanfaat untuk setiap organisasi, dan mampu mengurangi segala jenis pekerjaan ilegal di suatu organisasi.

Penelitian yang dilakukan oleh Lai \& Choong (2010), berdasarkan hasil survei terhadap Akuntan Profesional Malaysia dalam pengembalian pajak pribadi menunjukkan bahwa mayoritas $e$ filer memilih untuk menggunakan e-filing demi kenyamanan (55,8\%), dengan keyakinan mendapatkan pengembalian pajak lebih cepat $(16,8 \%)$ dan kecepatan pengarsipan. Terdapat beberapa faktor yang dapat mempengaruhi kinerja agen pajak (Hashim, Hamid, \& Rashid, 2018) berdasarkan kombinasi teori TPB (Theory of Planned Behaviour) dan ISS (Information System Success Theory) yaitu fungsionalitas, kualitas informasi, infrastruktur, dan pengetahuan. Upaya peningkatan kemudahan penggunaan, kegunaan, dan mengurangi risiko sistem pembayar pajak sangat penting untuk meningkatkan adopsi sistem e-filing (Azmi \& Bee, 2010). Selain itu kualitas sistem, kualitas informasi, dan juga kualitas layanan situs web memiliki pengaruh signifikan terhadap niat wajib pajak 
untuk menggunakan sistem (Lu \& Nguyen, 2016). Jumlah wajib pajak yang menggunakan $e$-filing dapat ditingkatkan dengan meningkatkan "ekpektasi kinerja" dari sistem e-filing pajak untuk mengirimkan formulir pengembalian pajak (Ibrahim, Lamidi, \& Alias, 2017).

PT Konimex adalah salah satu perusahaan yang sudah menggunakan sistem kearsipan elektronik, terutama pada Bagian Rekrutmen di PT Konimex. Seluruh data yang ada di Bagian Rekrutmen seperti data karyawan yang melamar, yang diterima, yang ditolak, maupun yang masuk dalam daftar hitam, semua disimpan pada sistem kearsipan elektronik yaitu Human Resource Information System atau biasa disebut HRIS. Sistem tersebut terhubung langsung dengan internet. Tujuan penelitian ini adalah untuk mengetahui efektivitas sistem kearsipan elektronik pada PT Konimex Solo.

\section{Kerangka Teori}

\section{Efektivitas}

Efektivitas adalah suatu keadaan yang menunjukkan sejauh mana rencana dapat tercapai. Semakin banyak rencana yang dapat dicapai, semakin efektif pula kegiatan tersebut, sehingga kata efektivitas dapat juga diartikan sebagai tingkat keberhasilan yang dapat dicapai dari suatu cara atau usaha tertentu sesuai dengan tujuan yang hendak dicapai. Media pembelajaran bisa dikatakan efektif ketika memenuhi kriteria, diantaranya mampu memberikan pengaruh, perubahan atau dapat membawa hasil (Anggriani, 2014).

Efektivitas memiliki arti berhasil atau tepat guna. Efektif merupakan kata dasar, sementara kata sifat dari efektif adalah efektivitas. Menurut Effendy, efektivitas adalah komunikasi yang prosesnya mencapai tujuan yang direncanakan sesuai dengan biaya yang sudah dianggarkan, waktu yang ditetapkan, dan jumlah personil yang ditentukan (Effendy, 1989).

Dari kedua pengertian di atas dapat disimpulkan bahwa efektivitas adalah pencapaian suatu tujuan yang telah direncanakan sebelumnya yang sesuai dengan biaya yang sudah dianggarkan, waktu yang telah ditetapkan dan jumlah personil yang telah ditetapkan pada saat perencanaan.

\section{Kearsipan Elektronik}

Menurut Haryadi (2009) arsip elektronik adalah kumpulan data yang disimpan dalam bentuk data scan yang dipindahkan secara elektronik atau dilakukan digital copy menggunakan resolusi tinggi, kemudian data tersebut disimpan dalam hard drive atau optical disk. Pengertian lain diungkapkan oleh Sedarmayanti (2005), arsip elektronik adalah sistem kearsipan yang menggunakan sarana pengolahan data elektronik.

Pendapat lain dikemukakan oleh The Georgia Archives, arsip atau dokumen elektronik dapat berasal dari berbagai bentuk, yaitu semua dokumen, kertas, surat, peta, buku (kecuali buku yang 
dikelola oleh perpustakaan), microfilm, magnetic tape, atau bahan lain tanpa menghiraukan bentuk fisik atau karakteristik, dibuat atau diterima menurut undang-undang (Sukoco, 2007). Sedangkan menurut International Standard Organization (ISO), arsip elektronik adalah informasi yang disimpan dalam berbagai bentuk, termasuk data dalam komputer, dibuat atau diterima serta dikelola oleh organisasi maupun orang dalam transaksi bisnis, dan menyimpannya sebagai bukti aktivitas (ISO/DIS 15489).

Dapat disimpulkan dari pengertian di atas bahwa sistem kearsipan elektronik adalah suatu sarana penyimpanan data dalam bentuk virtual yang dapat disimpan berupa surat, gambar, suara, dan lain sebagainya ke dalam komputer yang dikelola oleh organisasi maupun orang untuk kepentingan bisnis. Adapun efektivitas sistem kearsipan elektronik dapat diukur melalui empat dimensi yaitu:

a. Kecepatan

Kecepatan sistem kearsipan elektronik yaitu penemuan kembali data arsip yang disimpan. Jangka waktu yang dibutuhkan oleh user untuk menemukan data arsip yang telah disimpan dalam sistem kearsipan elektronik perusahaan. Melalui penggunaan media tersebut, maka media proses pencarian, penemuan, pendistribusian, dan juga pengolahan data akan dapat dilakukan dengan waktu singkat (Sugiarto \& Wahyono, 2005). Semakin cepat penemuan data arsip atau semakin sedikit waktu yang dibutuhkan untuk menemukan arsip menandakan sistem tersebut sudah baik.

b. Kemudahan

Kemudahan user dalam menggunakan sistem kearsipan elektronik. Sistem kearsipan elektronik yang baik dapat haruslah mudah digunakan oleh penggunanya. Salah satu kelebihan utama sistem kearsipan elektronik yaitu dapat memberikan kemudahan dalam pengelolaan dan manajemen $\operatorname{arsip}$ (Wahyono, 2004).

c. Kehematan

Biaya yang dikeluarkan perusahaan untuk membuat sistem kearsipan elektronik harus lebih kecil dibandingkan jika perusahaan harus menyediakan tempat untuk arsip, membeli lemari dan map dalam jumlah yang banyak setiap kurun waktu tertentu. Dengan penggunaan media elektronik kita bisa menggunakan lebih sedikit tenaga pikiran, dan juga biaya yang diperlukan dalam pengelolaan arsip (Sugiarto \& Wahyono, 2005). Maka dengan demikian sistem tersebut dapat dikatakan baik.

d. Keamanan

Dengan sistem kearsipan yang berbasis elektronik, keamanan dokumen akan lebih terjamin dengan adanya level keamanan bertingkat yang menggunakan username dan password . Dalam sistem kearsipan elektronik perusahaan wajib untuk memiliki sistem keamanan yang baik. Arsip yang tersimpan pun harus dijaga dengan aman supaya tidak sembarang orang dapat mengakses. 
Hal ini bertujuan untuk meminimalisir penyalahgunaan arsip oleh orang yang tidak bertanggung jawab.

Dalam pemilihan software yang digunakan dapat dilihat dari kemudahan mendapatkan perangkat lunak, kesesuaian sistem yang ada, dan kemudahan mengoperasikannya. Dari segi biaya untuk pemakaian dan pengembangan software pun juga perlu diperhatikan. Untuk mendapat software tersebut bisa didapatkan dengan cara membeli, menyewa, atau membuat software yang akan digunakan oleh perusahaan.

\section{Metodologi Penelitian}

Penelitian ini merupakan penelitian deskriptif yang menjelaskan suatu keadaan tertentu, tentang “Efektivitas Sistem Kearsipan Elektronik Human Resource Information System". Penentuan sampel menggunakan teknik purposive sampling. Purposive sampling merupakan teknik penentuan sampel dengan pertimbangan tertentu, kemudian pengambilan sampel secara sengaja sesuai dengan persyaratan sampel yang diperlukan (Sugiyono, 2013), yaitu karyawan yang mengakses sistem HRIS secara langsung. Informan dalam penelitian ini adalah karyawan yang mengakses sistem HRIS yaitu 1 orang Kepala Seksi Administrasi bagian Rekrutmen, 1 orang Staff Administrasi bagian Rekrutmen, 1 orang di bagian HRD, dan 1 orang di bagian Personalia PT Konimex Solo. Data dalam penelitian ini menggunakan data primer. Dalam memperoleh data penelitian menggunakan teknik in-depth interview yaitu untuk menemukan permasalahan secara lebih terbuka, di mana pihak yang diajak wawancara diminta pendapat, dan ide-idenya (Sugiyono, 2013).

Teknik analisis data dalam penelitian ini akan menggunakan teknik analisa deskriptif kualitatif. Teknik analisa deskriptif kualitatif adalah proses mencari dan menyusun data yang diperoleh dari hasil wawancara, catatan lapangan, dan bahan-bahan lain secara sistematis sehingga mudah dipahami dan temuannya dapat diinformasikan kepada orang lain (Sugiyono, 2013). Teknik analisis data yang digunakan meliputi 4 tahap yakni, pertama data collection memindahkan rekaman wawancara selama proses wawancara ke dalam bentuk tertulis secara rinci dan teliti. Kedua, data reduction yaitu mendeskripsikan identitas subyek, memilih hal-hal pokok, memfokuskan pada halhal yang penting, menentukan bentukan pola-pola perilaku yang ditunjukkan oleh masing-masing subyek selama proses wawancara. Ketiga, data display setelah data direduksi langkah selanjutnya yaitu menyajikan data dengan mengelompokkan hasil jawaban dari informan dengan tujuan agar data dapat terorganisasikan, tersusun dalam hubungan yang sama. Keempat, conclusion drawing menarik kesimpulan berdasarkan hasil jawaban dari informan. 


\section{Hasil dan Diskusi}

Hasil

\section{Human Resource Information System (HRIS)}

Awal mula diciptakannya sistem kearsipan elektronik HRIS yaitu dengan adanya permasalahan mengenai pemborosan pemakaian ruang untuk dokumen arsip fisik. Dokumen-dokumen arsip fisik dirasa sangat memenuhi ruangan menjadi faktor utama diciptakannya sistem kearsipan HRIS di PT Konimex. "Dulu sebelum ada sistem HRIS, perusahaan membutuhkan lemari yang banyak untuk menyimpan arsip dalam bentuk fisik dan itu membuat pemborosan ruang”.

Pada tahun 2004 PT Konimex membuat sistem kearsipan elektronik yang bernama HRIS. Human Resource Information System atau disingkat HRIS adalah sebuah sistem kearsipan elektronik yang berguna untuk menyimpan dokumen data karyawan yang melamar, sedang bekerja, dan yang sudah tidak bekerja lagi di PT Konimex. HRIS dibuat oleh anak perusahaan PT Konimex yaitu PT Sofco Graha. "Jadi HRIS itu sebuah sistem kearsipan elektronik yang digunakan untuk menyimpan dokumen calon karyawan dari yang diterima hingga yang ditolak bahkan diblacklist” menurut Informan 2.

Yang memegang peran penting dalam pengelolaan sistem kearsipan elektronik HRIS yaitu Bagian Rekrutmen, Human Resource Development, Personalia, IT atau biasa disebut bagian MIS (Management Information System) department, dan beberapa Manager Bagian. Selama ini dalam penggunaan HRIS terkadang mengalami hambatan pada jaringan yang sedang diriset oleh bagian IT. "Kadang tidak connect ke internet jadi tidak dapat digunakan. Biasanya setiap kurun waktu tertentu sistem HRIS itu diriset oleh bagian MIS/IT. Jadi sistem HRIS tidak dapat digunakan pada saat itu”. Hal itu menyebabkan HRIS tidak dapat dibuka untuk beberapa waktu. Namun hambatan ini sangat jarang terjadi.

Terdapat 4 (empat) dimensi untuk melihat efektivitas penggunaan sistem kearsipan elektronik sebagai berikut:

a. Kecepatan

Dalam sistem kearsipan elektronik HRIS sudah memiliki fasilitas untuk pencarian dokumen. Hal ini sangat membantu karena mempercepat proses penemuan kembali dokumen yang telah disimpan di HRIS. "Fasilitas ini wajib ada karena fasilitas ini yang mempercepat kegiatan kerja kita”. Oleh karena itu tidak memerlukan waktu yang panjang dalam penemuan kembali dokumen arsip yang telah disimpan pada sistem kearsipan elektronik HRIS.

Sistem penyimpanan dokumen yang digunakan dalam sistem kearsipan elektronik HRIS yaitu menggunakan nama. Kata tangkap nama dianggap mempercepat penemuan kembali dokumen yang telah disimpan. Kata tangkap nama digunakan karena dalam 1 (satu) folder nama seseorang terdapat dokumen yang lengkap mengenai seseorang tersebut. Sehingga kata tangkap nama menjadi 
pilihan yang paling tepat dalam menyimpan dokumen arsip untuk dokumen karyawan, "Kita pakai kata tangkap nama karena ini kan data karyawan jadi lebih mudah menggunakan nama karyawan”.

Pada sistem kearsipan elektronik HRIS tidak memiliki retensi otomatis untuk data yang tersimpan pada sistem kearsipan elektronik HRIS. Dari tahun 2004 hingga sekarang, segala dokumen yang telah diinput pada sistem kearsipan elektronik HRIS tidak pernah dimusnahkan. Sistem kearsipan elektronik HRIS dapat menyimpan dokumen yang sangat banyak karena PT Konimex memiliki server pribadi. Terkhusus pada bagian Recruitment dokumen calon karyawan yang tidak diterima bekerja di PT Konimex dalam bentuk hard file akan dimusnahkan setiap 2 (dua) tahun sekali. Pemusnahan dokumen fisik dapat menghemat ruangan, karena dokumen sudah diubah ke dalam bentuk softfile yang dapat disimpan dalam sistem kearsipan elektronik. "Di sistem ini tidak ada sistem retensi otomatis. Jadi semua dokumen yang telah disimpan tidak pernah dihapus. Jadi dokumen dari tahun 2004 masih ada di sistem penyimpanan elektronik HRIS. Ya karna kita punya server sendiri, jadi bisa muat banyak data” kata Informan 4.

Sistem kearsipan ini tidak melakukan pembagian dokumen ke dalam berbagai jenis kepentingan. Semua data yang tersimpan dianggap sama, kecuali untuk dokumen gaji dan tunjangan karyawan tidak dapat diakses sembarang orang. Hanya bagian Personalia dan beberapa manajer bagian yang dapat mengakses dokumen tersebut.

b. Kemudahan

Pengguna sistem kearsipan elektronik HRIS menganggap sistem tersebut mudah untuk dioperasikan (user friendly). Karena sistem ini menggunakan bahasa Indonesia dan terdapat panduan manual yang bisa dibaca. Hal itu membuat pengguna mudah sekali mengoperasikan sistem kearsipan elektronik HRIS. "Menurut saya mudah untuk digunakan karena dalam waktu yang sebentar saya sudah mengerti cara menggunakannya”.

Selain itu HRIS juga memiliki tampilan yang cukup menarik. Dari hasil wawancara, 4 (empat) informan mengatakan tampilan sudah cukup menarik dan dirasa sudah pas untuk sebuah sistem kearsipan elektronik. Menurut para informan tampilan pada sistem kearsipan elektronik HRIS tidak terlalu diperhatikan atau diprioritaskan oleh pengguna. Para informan lebih mementingkan fungsi dari sistem kearsipan elektronik HRIS sendiri. Jika sistem kearsipan elektronik HRIS bisa digunakan dengan baik sudah dirasa cukup oleh pengguna.

Sampai saat ini sistem kearsipan elektronik HRIS sudah bisa digunakan untuk menyimpan gambar, namun belum bisa digunakan untuk menyimpan suara. Hal ini tidak menghambat pengguna sistem kearsipan elektronik HRIS, karena sampai saat ini juga pihak PT Konimex tidak pernah menyimpan dokumen dalam bentuk suara. "Untuk saat ini HRIS belum bisa untuk menyimpan suara, namun sudah bisa untuk menyimpan gambar. Tapi itu tidak mengganggu kinerja kita, ya karena kita memang tidak pernah menyimpan suara”. 
Kemudian sistem kearsipan elektronik HRIS tidak memiliki pencatatan lokasi fisik dokumen yang tersimpan di HRIS. Pengguna bisa langsung mencetak dokumen yang tersimpan di HRIS jika dibutuhkan. Tetapi jika pengguna ingin menemukan kembali dokumen fisik yang asli, tentu saja pengguna harus mencarinya secara manual, "Di HRIS tidak ada pencatatan lokasi fisik dokumen. Jadi kalau kita butuh dokumen asli ya kita cari secara manual”. Hal ini memakan waktu yang cukup lama.

Sistem kearsipan elektronik ini juga terhubung dengan jaringan komputer. Sehingga komputer yang berada di dalam area PT Konimex dapat mengakses sistem kearsipan elektronik HRIS. Lain cerita jika pengguna ingin mengakses sistem HRIS di luar area PT Konimex. Pengguna yang ingin mengakses HRIS diluar area PT Konimex, pengguna harus melapor dan meminta bantuan dari pihak IT untuk disambungkan supaya sistem kearsipan elektronik HRIS dapat diakses diluar area PT Konimex. Penggunaan sistem kearsipan elektronik HRIS diluar PT memiliki jangka waktu untuk bisa mengakses sistem HRIS. Sebagai contoh jika seseorang karyawan ingin mengakses HRIS pada saat perjalanan dinas keluar kota selama 3 (tiga) hari, maka karyawan tersebut harus melapor dan meminta pihak IT untuk disambungkan ke laptop pribadinya. Kemudian pihak IT akan menyambungkan selama 3 (tiga) hari saja. Setelah lewat dari 3 (tiga) hari tersebut, secara otomatis laptop pribadi dari karyawan tersebut sudah tidak bisa digunakan untuk mengakses sistem kearsipan elektronik HRIS.

c. Kehematan

Terdapat 3 (tiga) orang informan yang peneliti wawancarai mengatakan tidak mengetahui biaya yang dikeluarkan untuk dapat menggunakan sistem kearsipan elektronik HRIS. Tetapi Personel Officer yang sudah bekerja selama 21 tahun, mengetahui bahwa PT Konimex membayar uang yang tidak diketahui jumlahnya setiap bulan ke PT Sofco Graha untuk berjaga-jaga jika suatu saat ada gangguan pada sistem kearsipan elektronik HRIS, PT Sofco akan segera menangani masalah tersebut. Menurut informan tersebut, dalam menggunakan sistem kearsipan elektronik HRIS dianggap lebih murah dibandingkan dengan sistem kearsipan manual dari segi biaya. "Kalau untuk jumlah biaya saya tidak tahu. Namun setiap bulan Konimex membayar ke PT Sofco Graha untuk berjaga-jaga jika ada gangguan, hampir sama kayak asuransi gitu, jadi PT Sofco Graha selalu siap siaga jika dibutuhkan oleh PT Konimex. Tapi kalo dikira-kira secara awam pun tetap lebih murah jika menggunakan sistem HRIS”.

Adapun sumber daya yang dihemat dalam penggunaan sistem kearsipan elektronik HRIS yaitu menghemat ruang dan alat. Penghematan ruang dikarenakan segala dokumen fisik untuk dokumen calon karyawan yang tidak dapat bekerja di PT Konimex akan dimusnahkan setiap 2 tahun sekali. Dengan semakin banyaknya dokumen yang disimpan dalam bentuk softfile di sistem kearsipan elektronik HRIS membuat perusahaan tidak perlu membeli lemari dan map secara terus menerus. 
Selain itu ruang kantor akan lebih luas dengan pengurangan lemari-lemari penyimpanan yang sudah tidak dibutuhkan lagi. "Menghemat ruang dan alat ya, karena setiap 2 tahun sekali kan dokumen karyawan yang ditolak dimusnahkan jadi akan menghemat ruang dan alat yang biasanya digunakan untuk menyimpan, karena yang terpenting dokumen sudah ada di HRIS.” Jelas Informan 2.

\section{d. Keamanan}

Jika dilihat dari segi keamanan, sistem kearsipan elektronik HRIS memiliki sistem keamanan yang menggunakan username dan password. Hal ini adalah salah satu usaha perusahaan untuk menga ki username dan password untuk sistem penyimpanan elektronik HRIS”. Selain itu password harus diubah setiap 3 (tiga) bulan sekali. Password untuk HRIS menggunakan kata sandi yang sulit sehingga orang lain tidak dapat menebak kata sandi apa yang digunakan. Tak hanya itu, jika pada saat login pengguna salah memasukan password sebanyak maksimal 2 (dua) kali, maka secara otomatis username tersebut akan terkunci atau terblokir dan tidak dapat digunakan. Untuk bisa membukanya kembali pengguna harus menemui bagian IT.

Pembedaan akses dokumen pada sistem kearsiapan elektronik HRIS dibedakan berdasarkan bagian. Bagian Rekrutmen hanya bisa mengakses dokumen yang bersangkutan dengan bagian Rekrutmen. Jadi bagian Rekrutmen tidak dapat mengakses dokumen yang disimpan oleh bagian HRD dan Personalia, dan begitulah sebaliknya. "Perbedaan dalam mengakses HRIS hanya dibedakan berdasarkan bagian, karna saya di bagian Rekrutmen ya saya hanya bisa mengakses dokumen karyawan yang bersangkutan dengan kerjaan saya saja”.

\section{Diskusi}

\section{Kecepatan Proses Pencarian Dokumen}

Bagian ini akan menunjukan apakah menu aplikasi yang ada dapat mempercepat proses pencarian dokumen yang ada. Hasil penelitian memperlihatkan bahwa terdapat kelebihan dalam aspek kecepatan pada sistem kearsipan elektronik HRIS, yaitu:

a. Pada sistem kearsipan elektronik HRIS sudah memiliki fasilitas pencarian dokumen, sehingga mempercepat penemuan data yang tersimpan pada sistem.

b. Dalam pencarian dokumen, sistem kearsipan elektronik HRIS menggunakan kata tangkap nama. Kata tangkap nama mempercepat penemuan kembali dokumen.

c. Sistem HRIS ini memiliki daya tampung dokumen yang sangat besar, jadi memungkinkan untuk menyimpan dokumen dalam jumlah yang banyak.

Selain kelebihan dalam beberapa hal di atas, adapun beberapa kelemahan pada aspek kecepatan sistem yaitu: 
a. Sistem kearsipan elektronik HRIS ini tidak melakukan pembagian dokumen menurut jenis kepentingannya. Hanya pada dokumen gaji dan tunjangan yang dibedakan dan hanya bisa diakses oleh bagian personalia dan beberapa manajer bagian.

b. Pada sistem ini masih belum ada fasilitas retensi otomatis. Karena dokumen yang sudah disimpan pada sistem kearsipan elektronik HRIS tidak pernah dimusnahkan. Maka dokumen yang berada dalam sistem akan disimpan selamanya. Hal ini ditunjang dengan adanya server pribadi perusahaan yang memiliki daya tampung yang besar.

Dari hasil temuan tersebut, terlihat bahwa dalam hal kecepatan proses dalam pencarian dokumen (Gie, 2000), sistem ini sudah cukup cepat dalam pencarian dokumen yang disimpan pada sistem kearsipan elektronik HRIS.

\section{Kemudahan Penggunaan Sistem}

Pada bagian ini menggambarkan tentang sistem kearsipan elektronik yang ada saat ini dapat digunakan dan dioperasikan dengan mudah oleh karyawan bagian Rekrutmen PT Konimex. Hasil penelitian memperlihatkan bahwa pengguna mendapatkan beberapa kemudahan dengan adanya sistem kearsipan elektronik HRIS.

1. Kemudahan sistem yang dapat diakses secara multiuser dengan adanya sistem jaringan. Dengan adanya sistem jaringan membuat sistem kearsipan elektronik HRIS dapat diakses di komputer lain dengan beberapa pengguna lain sekaligus. Sistem ini sudah berbasis web jadi bisa dioperasikan secara online. Hal ini memudahkan pengguna untuk mengakses sistem ini dari komputer lain atau tempat lain.

2. Kemudahan dalam penyimpanan dokumen dalam bentuk gambar. Adanya ketersediaan fasilitas untuk menyimpan gambar pada sistem kearsipan elektronik HRIS yang memudahkan pengguna dalam penyimpanan gambar.

3. Kemudahan untuk pengoperasian sistem kearsipan elektronik HRIS dengan menu yang tersedia saat ini. Namun terdapat beberapa kelemahan pada sistem kearsipan elektronik HRIS yaitu:

a. Sistem penyimpanan elektronik HRIS belum bisa digunakan untuk menyimpan suara.

b. Tidak adanya fasilitas pencatatan lokasi fisik dokumen. Hal ini menyebabkan jika karyawan membutuhkan data yang asli, karyawan tersebut harus mencarinya secara manual. Maka belum mempermudah pengguna dalam pencarian hardfile dari arsip yang dicari.

Dari hasil temuan tersebut, terlihat bahwa sistem kearsipan elektronik HRIS di PT Konimex Solo sudah cukup mudah digunakan oleh user namun masih memiliki beberapa kekurangan, khususnya pada aspek kemudahan. Dengan demikian sistem kearsipan elektronik HRIS masih perlu dikembangkan lagi untuk mendukung kegiatan kerja dimasa yang akan datang pada PT Konimex. 
Sehingga sistem kearsipan elektronik yang ada sudah cukup memenuhi syarat yaitu, dapat memberikan kemudahan dalam pengelolaan dan manajemen arsip (Wahyono, 2004).

\section{Kehematan dalam Penggunaan Sistem}

Bagian ini menggambarkan apakah dengan adanya sistem kearsipan elektronik lebih menghemat sumber daya yang ada dalam penggunaannya. Menurut Sugiarto \& Wahyono (2005), dengan penggunaan media elektronik kita bisa menggunakan lebih sedikit tenaga pikiran, dan juga biaya yang diperlukan dalam pengelolaan arsip. Seperti dengan teori yang ada, dengan menggunakan sistem kearsipan elektronik HRIS, perusahaan dapat menghemat ruangan, alat dan biaya. Penyimpanan dokumen dalam bentuk softfile membuat perusahaan tidak perlu membeli lemarilemari dan map-map dalam jumlah yang banyak untuk menyimpan dokumen fisik.

\section{Keamanan Dokumen}

Pada bagian ini menggambarkan apakah sistem kearsipan elektronik yang digunakan saat ini sudah terjamin keamanannya dalam menyimpan dokumen. Sistem kearsipan elektronik HRIS memiliki sistem keamanan dengan menggunakan username dan password pada saat login. Sama seperti dengan hasil penelitian sebelumnya, dalam sistem yang diterapkan di YPTKSW juga memiliki level keamanan bertingkat dengan menggunakan ID pengguna dan password (Silintowe \& Sugiarto, 2013). Bahkan jika pengguna salah memasukan password maksimal 2x, username akan terblokir secara langsung.

Selain itu, dokumen yang tersimpan pada HRIS akan dilakukan back-up setiap waktu tertentu oleh bagian MIS/IT perusahaan untuk membuat data menjadi lebih aman jika terjadi kerusakan sistem komputer. Dengan melakukan back-up data ke disket atau CD akan membuat data lebih aman karena jika terjadi kerusakan sistem komputer, data masih bisa diselamatkan melalui back-up tersebut (Sugiarto \& Wahyono, 2005). Sistem kearsipan elektronik HRIS sudah memiliki sub menu user management yang dibedakan berdasarkan bagian divisi. Hal ini bertujuan untuk menjamin keamanan pengguna sistem dengan adanya user level dan username untuk menjamin autorisasi setiap pengguna.

Dari penjelasan tersebut, terlihat bahwa dalam aspek keamanan dokumen yang tersimpan pada sistem kearsipan elektronik HRIS sudah sangat baik dan terjamin keamanannya. Dengan adanya username dan password, pemberlakuan back-up pada setiap waktu tertentu, dan pembedaan autoritisasi akses membuat sistem kearsipan elektronik HRIS sudah sangat baik dalam menjamin keamanan dokumen yang tersimpan. 


\section{Simpulan}

Berdasarkan hasil penelitian yang telah diperoleh, peneliti dapat menarik beberapa kesimpulan dari efektivitas sistem kearsipan elektronik HRIS (Human Resource Information System) pada bagian Recruitment PT Konimex Solo, yaitu:

a. Dalam aspek kecepatan, sistem kearsipan elektronik HRIS sudah cukup cepat dalam pencarian dokumen yang disimpan dalam sistem. Hal ini dibuktikan dengan adanya fasilitas pencarian dokumen pada sistem, serta kata tangkap yang digunakan yaitu menggunakan kata tangkap nama melihat data yang disimpan adalah dokumen karyawan maka akan lebih cepat menggunakan kata tangkap nama dalam proses pencarian dokumen di sistem HRIS. Namun masih ada beberapa kekurangan pada sistem kearsipan elektronik HRIS yaitu masih belum adanya fasilitas retensi otomatis pada sistem dan belum adanya pembagian dokumen menurut jenis kepentingannya. Dengan demikian diperlukan adanya fasilitas retensi otomatis dan pembagian dokumen menurut jenis kepentingannya supaya mempercepat dalam penemuan dokumen yang disimpan.

a. Pada aspek kemudahan, sistem HRIS dinilai sudah cukup mudah digunakan oleh pengguna (user). Hal ini dapat dilihat dari hasil wawancara bahwa pengguna dengan sangat mudah memahami dan menggunakan sistem dalam waktu singkat. Tak hanya itu, dengan adanya sistem jaringan yang membuat sistem kearsipan elektronik HRIS dapat diakses dikomputer lain dengan beberapa pengguna lain sekaligus. Kemudian pada sistem HRIS juga sudah dapat digunakan untuk menyimpan gambar. Tetapi sistem kearsipan elektronik HRIS masih belum bisa digunakan untuk menyimpan suara dan masih belum memiliki fasilitas pencatatan lokasi fisik dokumen yang menyebabkan pengguna kesulitan untuk mencari dokumen fisik yang disimpan. Dengan demikian diperlukan penambahan fasilitas pencatatan lokasi fisik dokumen supaya memudahkan pengguna dalam penemuan kembali dokumen fisik yang disimpan.

b. Dalam aspek kehematan, sistem kearsipan elektronik HRIS dapat menghemat beberapa sumber daya yaitu, ruangan, alat, dan biaya yang harus dikeluarkan. Karena dengan adanya sistem kearsipan elektronik HRIS ini, perusahaan tidak perlu menyimpan dokumen-dokumen fisik yang sangat banyak. Perusahaan tidak perlu lagi membeli lemari-lemari dan map-map untuk menyimpan arsip fisik. Namun demikian tetap perlu ditingkatkan lagi terkait efisiensi dalam menggunakan peralatan kearsipan.

c. Pada aspek keamanan dapat dilihat bahwa sistem kearsipan elektronik HRIS sudah sangat baik. Hal itu ditunjukan dengan adanya username dan password untuk masuk ke sistem HRIS. Tak hanya itu sistem kearsipan elektronik HRIS juga sudah memiliki sub menu user management yang dibedakan berdasarkan divisi. Sistem ini pun hanya bisa diakses di dalam area PT Konimex saja, dan sistem kearsipan elektronik HRIS juga melakukan back-up setiap waktu tertentu. 
Peningkatan dan inoavasi baru dalam keamanan sistem kearsipan elektronik perlu terus dilakukan.

\section{Saran}

Saran lain yang dapat peneliti berikan kepada PT Konimex Solo yaitu diperlukan pengembangan sistem kearsipan elektronik HRIS supaya sistem ini dapat digunakan semaksimal mungkin yang nantinya dapat mewujudkan efektivitas dan efisiensi dalam pengelolaan arsip di PT Konimex Solo di masa yang akan datang.

\section{Arah Penelitian di Masa Depan}

Penelitian ini meneliti terkait sistem kearsipan elektronik yang ada di salah satu bagian suatu perusahaan yaitu Human Resource Department, PT Konimex Solo. Penelitian yang akan datang diharapkan dapat lebih mengeksplorasi terkait sistem kearsipan elektronik secara menyeluruh pada suatu perusahaan, sehingga dapat lebih menggali gambaran umum sistem yang ada pada suatu perusahaan. 


\section{Referensi}

Alam, M. B. (2015). Development and Implementation of E-Filing System. Daffodil International University, Dhaka, Bangladesh. Diambil kembali dari http://dspace.library.daffodilvarsity.edu.bd:8080/handle/20.500.11948/3256

Anggriani, S. (2014, Desember 27). Literatur Buku. Dipetik Juni 09, 2017, dari Literatur Buku: http://literaturbook.blogspot.co.id/2014/12/pengertian-efektivitas-dan-landasan.html

Azmi, A. C., \& Bee, N. L. (2010). The Acceptance of the e-Filing System by Malaysian Taxpayers: a Simplified Model. Electronic Journal of e-Government, 8(1), 13-22. Diambil kembali dari www.ejeg.com

Effendy, O. U. (1989). Kamus Komunikasi. Bandung: Mandar Maju.

Gie, T. L. (2000). Administrasi Perkantoran Modern. Yogyakarta: Liberty Offset.

Haryadi, H. (2009). Administrasi Perkantoran Untuk Manajer dan Staf. Jakarta: Visimedia.

Hashim, N., Hamid, N., \& Rashid, N. (2018). Assessing Job Performance of Tax Agents via EFiling System. International Journal of Academic Research in Business and Social Sciences, 8(11), 1369-1378.

Ibrahim , I., Lamidi, W., \& Alias, M. (2017). Perceived Usefulness and the Acceptance of Tax EFiling System: Malaysia and Nigeria Cases. 4th International Conference on e-Commerce, (hal. 170-176). Putrajaya, Malaysia. Diambil kembali dari http://icoec.my/download/icoec_2017/ICoEC2017_147.pdf

Lai, M.-L., \& Choong, K.-F. (2010). Motivators, Barriers and Concerns in Adoption of Electronic Filing System: Survey Evidence from Malaysian Professional Accountants. American Journal of Applied Sciences, 7(4), 562-567. doi:http://dx.doi.org/10.3844/ajassp.2010.562.567

Lu, N. L., \& Nguyen, V. T. (2016). Online Tax Filing: e-Government Service Adoption Case of Vietnam. Modern Economy, 7, 1498-1504. doi:10.4236/me.2016.712135

Sedarmayanti. (2005). Tata Kearsipan Dengan Memanfaatkan Teknologi Modern. Bandung: Mandar Maju.

Silintowe, Y. B., \& Sugiarto, A. (2013). Pengembangan Sistem Kearsipan Elektronik Berbasis Client-Server. Efektivitas Penerapan Manajemen Kearsipan Elektronik, 38-49.

Sugiarto, A., \& Wahyono, T. (2005). Manajemen Kearsipan Modern. Yogyakarta: Gava Media.

Sukoco, B. M. (2007). Manajemen Administrasi Perkantoran Modern. Surabaya: Penertbit Erlangga.

Wahyono, T. (2004). Sistem Informasi: Konsep Dasar, Analisis Desain dan Implementasi. Yogyakarta: Penerbit Graha Ilmu. 